DOI: $10.2478 / \mathrm{v} 10025-010-0019-4$

JOURNAL OF WATER

AND LAND DEVELOPMENT

J. Water Land Dev. No. 13a, 2009: 53-69

\title{
Tendencies of changes in the chemical composition of precipitation in the Wielkopolski National Park
}

\author{
Barbara WALNA ${ }^{1)}$, Iwona KURZYCA ${ }^{2}$ \\ 1) Ecological Station of the Adam Mickiewicz University, Jeziory, 62-050 Mosina, PO Box 40, Poland \\ 2) Department of Water and Soil Analysis of the Adam Mickiewicz University, Drzymały 24, 60-613 \\ Poznań, Poland
}

\begin{abstract}
The results are presented of chemical studies on precipitation based on multi-year observations (1992-2007) carried out in the Wielkopolski National Park (WNP). They are compared with the monitoring data obtained by stations grouped in the European Monitoring and Evaluation Programme (EMEP) network. It was found that over the study period the $\mathrm{pH}$ of precipitation tended to grow systematically, thus contributing to a decrease of the annual deposition of $\left(\mathrm{H}^{+}\right)$ions. The trend lines of changes in the deposition of hydrogen ions have similar slope coefficients, which indicates similar rate of changes. The year with the lowest $\mathrm{pH}$ was 1994, in which the mean annual $\mathrm{pH}$ was 3.92. In turn, the acidification level was the lowest in 2006 with $\mathrm{pH}-4.80$. The deposition of hydrogen ions at all stations often exceeded $20 \mathrm{mg} \cdot \mathrm{m}^{-2} \cdot \mathrm{year}^{-1}$, and at the WNP station it even reached $70 \mathrm{mg} \cdot \mathrm{m}^{-2}$ in 1994.

The deposition of acid-forming ions was also analysed. Predominant among them were sulphate ions, but their deposition showed a declining tendency with time. Their maximum values were recorded in precipitation in the WNP $-707 \mathrm{mg} \mathrm{S}-\mathrm{SO}_{4} \cdot \mathrm{m}^{-2}$ (2002) and $260 \mathrm{mg} \mathrm{N}-\mathrm{NO}_{3} \cdot \mathrm{m}^{-2}$ (2007). It was found that the $\mathrm{NO}_{3} / \mathrm{SO}_{4}$ eq/eq ratio tended to increase, which is indicative of changes in the composition structure of precipitation. This effect resulted from the decrease in $\mathrm{SO}_{2}$ emission in the Wielkopolska region and from the increase in $\mathrm{NO}_{\mathrm{x}}$ emission caused by car traffic in the Park and along its border.

Calcium dominated among the deposited alkaline cations - its share exceeded $50 \%$. The figures recorded for potassium and calcium deposition by lowland EMEP stations were several times lower than those obtained in the WNP and lower than the mean for Poland. Over the last years one can note a stabilisation in the amount of deposited cations.
\end{abstract}

Key words: acidification, deposition, $\mathrm{pH}$, throughfall

\section{INTRODUCTION}

The Wielkopolski National Park (mid-west Poland) is a protected region that needs special care of its woodland, which occupy up to $61 \%$ of its area. However, nature in the Park is threatened since it is located close to the Poznan municipality 
( $25 \mathrm{~km}$ away), and to nearby towns of a few thousand inhabitants, especially highly industrialized Luboń of a population of 30 thousand (MICHAŁOWSKI et al., 2003; KOWALSKI, 2004). The development of the transport system with roads both on the Park's edges and those running through is a major source of air pollution (GÓRSKI and PrZYBYŁeK, 2003). The pollution caused by the industrial plants situated a few or a dozen or so kilometres from the forest complex, or pollution carried from distant areas results in elevated amounts of sulphates, chlorides and fluorides (KRYSIAK, 2005; WALNA and KURZYCA, 2007). This pollution in the form of dry and wet deposition influences the chemical composition of precipitation (ASTEL et al., 2007; WALNA and SIEPAK, 1999). In the last few years, a major decline in the emission of sulphur compounds has been registered in Poznań, though changes in the emission for the Wielkopolska region as a whole have not been that significant (KRYSIAK, 2005; POLKOWSKA et al., 2005; Statistical Data, 2005). The main object of the undertaken research was the impact of changes in the amount and chemical composition of precipitation on the elements of the Park ecosystem over the last few years and the identification of possible protective measures for the WNP woodland. Examples of such an application of climatic studies are publications concerning the growth dynamics of oaks (CZERNIAK et al., 2008; UFNALSKI and SIWECKI, 2002).

The aim of this article is to discuss the results of a chemical study of precipitation in the years 1992-2007. It focused on both, the amount of precipitation and the chemical composition of rainwater collected in open terrain and under tree crowns, including the deposition of acid-forming components. Tendencies of changes were also identified.

\section{METHODS}

\section{SAMPLING SITE}

Observations of precipitation, both in quantitative and qualitative terms, are carried out at the Jeziory Ecological Station of the Adam Mickiewicz University located in the centre of the Wielkopolski National Park (WNP). The site is located at $52^{\circ} 11^{\prime} \mathrm{N}$ and $16^{\circ} 54^{\prime} \mathrm{E}$ at an altitude of $82 \mathrm{~m}$ a.s.l. The landscape of the Park is a result of numerous geomorphologic processes linked to the movement of a glacier. A substantial part of the Park is covered with poor soils developed from loose or weakly loamy sand where pine forests and mixed pine - oak forests are dominating. Brown soil of higher quality is home to acid oak forests, and oak-hornbeam forests. The sampling place is a forest clearing in a protected area surrounded by extensive patches of woodland; some $200 \mathrm{~m}$ away there is a road with light traffic. Rainwater was collected on a daily basis and analysed as soon as possible after the precipitation event. The trees are about 40 years old and $30 \mathrm{~cm}$ in diameter. 
The research was initially limited to basic physico-chemical parameters, but since 2002 it has been expanded to include regular monitoring of the chemical composition of precipitation. Quantitative studies were made using a Hellmann rain gauge and automatically (an Aster station). Samples of bulk precipitation for chemical analyses were collected with the help of one collector $56 \mathrm{~cm}$ in diameter placed $1.2 \mathrm{~m}$ above the ground in a forest clearing and the similar one under oak trees.

\section{ANALYTICAL METHODS}

$\mathrm{pH}$ and electric conductivity were measured on the spot, and the ionic composition was determined with DIONEX 120 chromatograph in the Department of Water and Soil Analysis of the Adam Mickiewicz University in Poznan. Before the transfer, the samples were filtered through a filter with a pore diameter of $0.45 \mu \mathrm{m}$ and, if necessary, kept in refrigerator, out of light. The reliability of the results was checked against reference material suitable for samples of a low ionic strength RAIN 95. Analytical details were described in another paper (POLKOWSKA et al., 2005). An essential element of rainfall analysis was the set of meteorological data obtained at the Station through the steady automatic monitoring of a dozen or so parameters. Measurements were registered every 10 minutes. An automatic heating of the collector enabled to gather precipitation in the winter.

\section{RESULTS AND DISCUSSION}

\section{RAINFALL - ANNUAL AND MONTHLY}

Significant differences in the annual rainfall were noted during the study period (Tab. 1). The figures varied from a minimum of $338 \mathrm{~mm}$ in 2003 to $656 \mathrm{~mm}$ in 2007. The average was $536 \mathrm{~mm}$, nearly equal to the multi-year mean for the area (528 mm) (WoŚ, 1994). The years with below-average precipitation were 1992, 1995, 2003 and 2004. Those with precipitation above the average were 1993, 1994, 2002 and 2007. These measurements show that dry years alternated with those rich in rainfall.

On account of the plants growth regime, the rainfall during the vegetation season (1 Apr.-15 Nov. for oak tree in the Wielkopolska region) was also calculated. The analysis of the data showed that, aside from the year 1992 when the rainfall during the vegetation season was only $204 \mathrm{~mm}$, a period significantly deficient in rainfall was that from 2003 to 2005 when the rainfall did not exceed $300 \mathrm{~mm}$. To describe precipitation variability it is also important to present its structure in the consecutive months. In the 1990s and before the month richest in precipitation was 


\begin{tabular}{|c|c|}
\hline 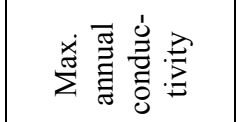 & 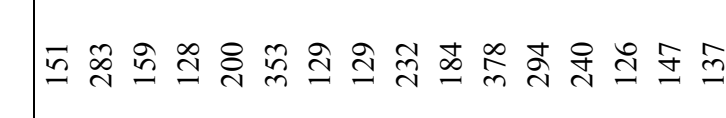 \\
\hline 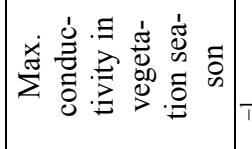 & 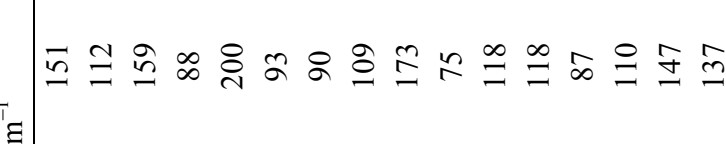 \\
\hline 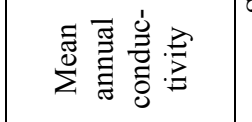 & 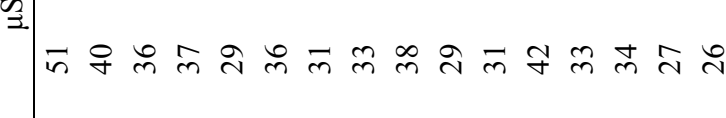 \\
\hline 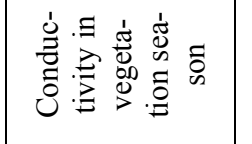 & 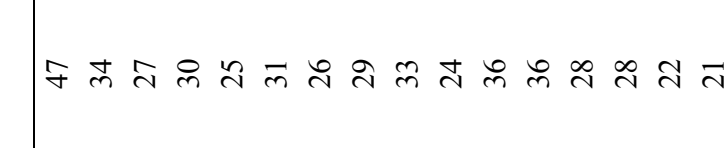 \\
\hline 运要焉 & 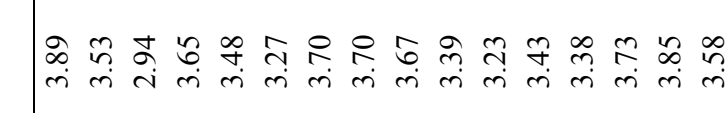 \\
\hline 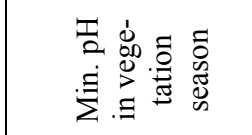 & 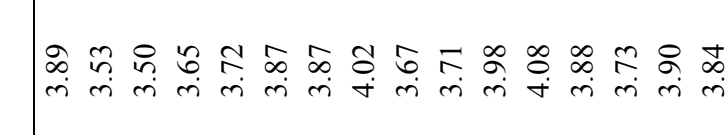 \\
\hline 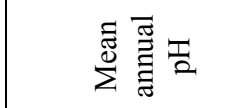 & 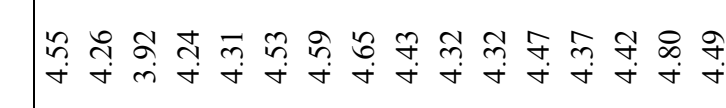 \\
\hline 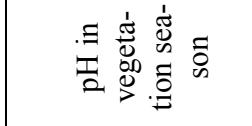 & 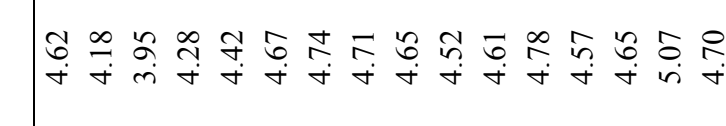 \\
\hline 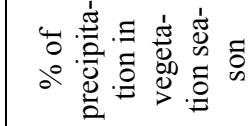 & กล \\
\hline 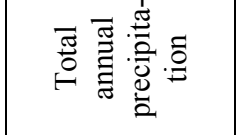 & 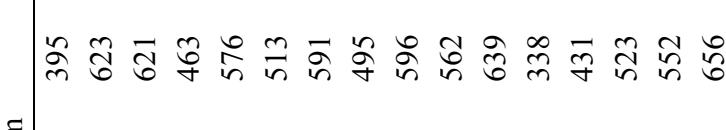 \\
\hline 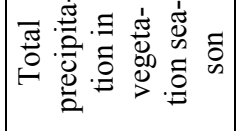 & 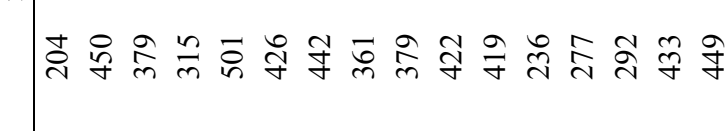 \\
\hline 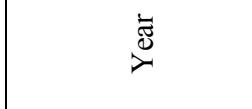 & 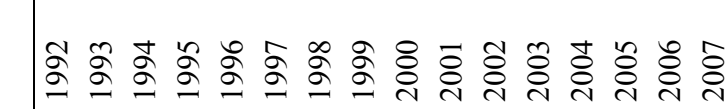 \\
\hline
\end{tabular}


usually July (WoŚ, 1994), e.g. $1993-151 \mathrm{~mm}, 1996-185 \mathrm{~mm}$, or $1997-171$ $\mathrm{mm}$. However, when comparing monthly totals in the recent years (2000-2007), one does not observe the regularity described so far: a fairly even distribution of precipitation over the individual months and a peak in July. In those years the maximum precipitation in July was only noted in 2007 (126 mm). In 2006, exceptionally low precipitation was recorded in June and July $(18 \mathrm{~mm}$ and $16 \mathrm{~mm}$, respectively) and in September $(20 \mathrm{~mm})$, while the maximum precipitation occurred in August (188 mm) (Fig. 1). In 2005, the months with the lowest precipitation in the vegetation season were June $(9 \mathrm{~mm})$ and October $(6 \mathrm{~mm})$. The situation seemed favourable in 2004 since despite the deficiency of precipitation, its structure was regular.

It is also worth noting that intensive rainfalls of short duration have recently been observed. The automatic measuring system repeatedly recorded more than $5 \mathrm{~mm}$ of rain that fell in 10 minutes. Such a violent character of the event, accompanied by a gusty wind, may cause a lot of damage.

\section{THE pH OF PRECIPITATION}

The most important parameter describing possible negative effects that precipitation may have on vegetation and soil is $\mathrm{pH}$ of the rainwater. Table 1 shows weighted mean annual $\mathrm{pH}$ values for the years 1992-2007. The mean annual $\mathrm{pH}$ varied from a minimum of 3.92 in 1994 to a maximum of 4.80 in 2006. On average, the $\mathrm{pH}$ for this period was 4.4. An analysis of the 16 years of observations indicated a slightly increasing tendency (Fig. 2) but it wasn't statistically significant $(r=0.4124$ at $p=0.1125)$. The use of a polynomial function gave better approximation. However, it was difficult to find an adequate justification for such a form.

Also worth noting were the extremely low $\mathrm{pH}$ values of precipitation, even below $\mathrm{pH} 3.0$ (1994). The minimum $\mathrm{pH}$ varied from 2.94 to 3.89 , or 3.5 on average. The Table 1 also shows weighted annual means of precipitation $\mathrm{pH}$ for the vegetation season. Because lower $\mathrm{pH}$ of precipitation in winter is a well-known regularity, mean $\mathrm{pH}$ in the vegetation season (4.6) was higher than the annual mean. The minimum $\mathrm{pH}$ in the vegetation season was usually lower than 4.0, with the lowest, 3.50, recorded also in 1994. Unfortunately, such a low $\mathrm{pH}$ in the growing season may cause damage to the outer layer of a leaf and let the rain inside the plant tissue, which can trigger some adverse physiological processes (ASHENDEN, 2002).

The structure of precipitation is presented in Table 2. It rests on the division of all the precipitation events in a year into groups according to their $\mathrm{pH}$ range (JANSEN et al., 1988). Exceptional precipitation was that occurring between 1994 and 1996, 2000 and 2002, and 2004 and 2005, since the proportion of episodes with a pH lower than 4.6 was near or over $60 \%$. A record year for rain acidity was 1994, when $91 \%$ of the precipitation had $\mathrm{pH}$ below 4.6 . 

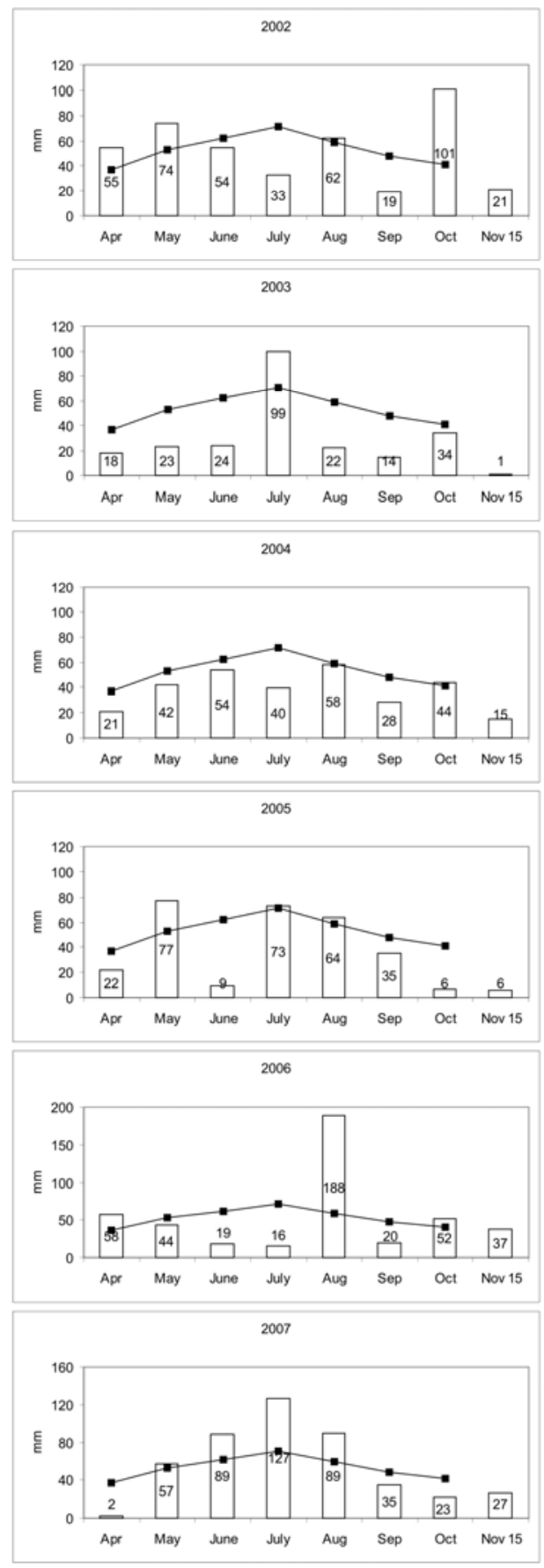

Fig. 1. Monthly sums of precipitation in the vegetation seasons (2002-2007) against the multi-year mean 


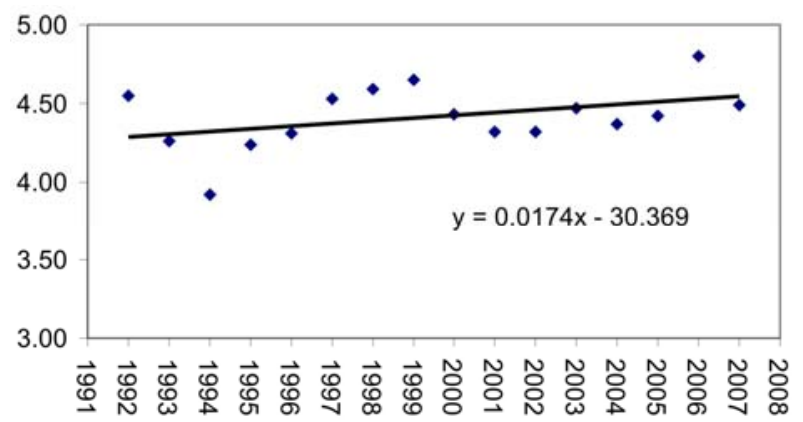

Fig. 2. Tendency of changes in the $\mathrm{pH}$ of precipitation - annual weighed mean, 1992-2007

In periods of no precipitation, the surface of plants gathers deposits and dust which, when it rains, partly dissolve and get into the ground. The amount of deposits and dust depends, among others, on time intervals between the rainfalls, the size of leaves, and the wind force. The amount of rainfall that reaches the ground depends on tree species, their age, habitat, and other factors. Therefore, any comparison of $\mathrm{pH}$ and composition of the throughfall with data from another place is difficult. However, the obtained figures are important since they expand our quantitative and qualitative knowledge of dry deposition, so hard to collect and analyse. In the period under study (1992-2007), rainfall was collected under oaks (ca. 40 years old). The mean annual $\mathrm{pH}$ of the throughfall varied from 3.8 in 1994 to 4.8 in 1999 and 2007 being 4.6 on average. The minimum figures noted in subsequent consecutive years were close to 4.0 or lower. The lowest $\mathrm{pH}$ recorded was 2.93 in 1994 . The increasing trend of the annual average of throughfall $\mathrm{pH}$ over the study period was statistically significant as the correlation coefficient equalled $r=0.6516$ at $p=0.0062$ (Fig. 3).

A measure of the amount and composition of dry deposition gathered on leaves could be the electric conductivity of the throughfall. The average figures varied from $77 \mu \mathrm{S} \cdot \mathrm{cm}^{-1}$ (in 1997,1998 and 2007) to $149 \mu \mathrm{S} \cdot \mathrm{cm}^{-1}$ (1992). The figures in each year were two to four times higher than the conductivity of rainfall in open terrain. The mutual relations and tendencies of changes are shown in Fig. 4. For conductivity in open terrain, the decreasing trend was statistically significant as the correlation coefficient equalled $r=-0.6002$ at $p=0.0140$, while for the throughfall conductivity the correlation coefficient equalled $r=-0.2682$ at $p=$ 0.3152 . It should be noted that the conductivity of throughfall varied much more than the conductivity of rainfall in the open area, which can be observed when comparing the maximum figures of electric conductivity in the subsequent consecutive years. These figures exceeded $1000 \mu \mathrm{S} \cdot \mathrm{cm}^{-1}$ (1 $370 \mathrm{in} 1996$ and 1,470 in 2000). The tendency of changes in the electric conductivity of precipitation, both in the open and in throughfall, is downward, which is indicative of declining pollution of the rainwater. 


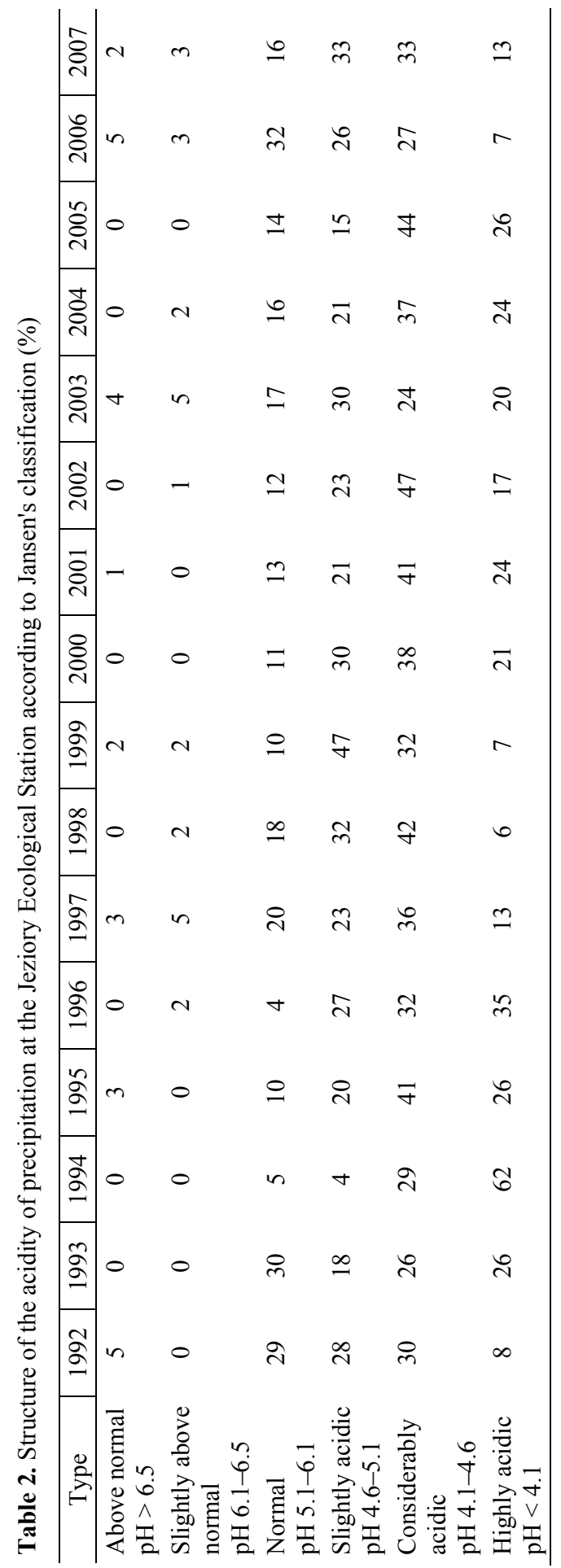




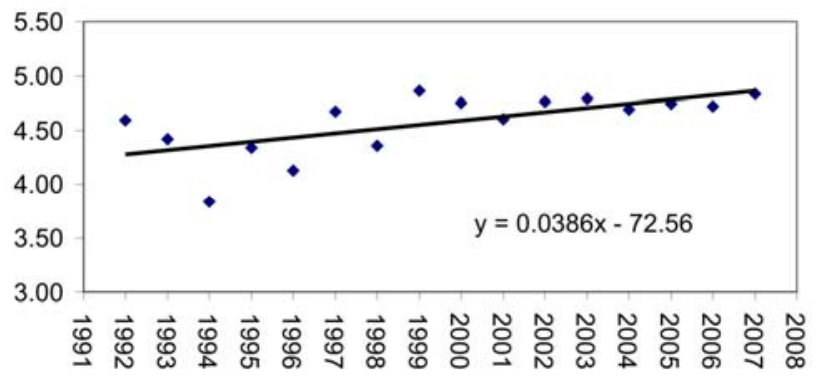

Fig. 3. Tendency of changes in the $\mathrm{pH}$ of throughfall, 1992-2007

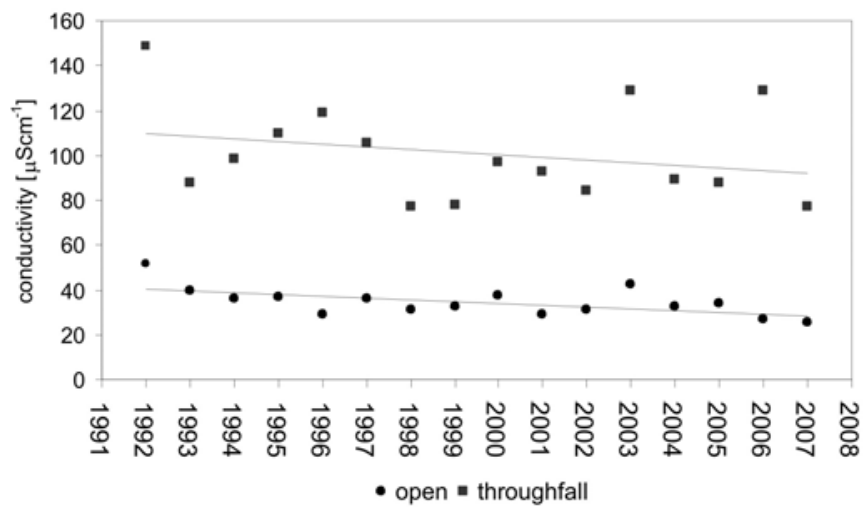

Fig. 4. Tendency of changes in the annual conductivity of precipitation in open terrain and in throughfall, 1992-2007

\section{THE CHEMICAL COMPOSITION OF PRECIPITATION - DEPOSITION OF POLLUTION}

The effect that the components of precipitation exert on vegetation can be estimated by analysing either the concentration or deposition per unit area $\left(\mathrm{m}^{2}, \mathrm{ha}\right)$ in a given time interval (month, year) calculated on the basis of the concentration and the amount of rainfall. Both methods describe precipitation, though each in a slightly different way. Therefore, the discussion below will concern changes in the concentrations and/or the deposition.

When considering the impact of precipitation on woodland, the abovementioned results of $\mathrm{pH}$ measurement should be supplemented by annual figures of hydrogen ion deposition calculated as the sum of the products of total rainfall and hydrogen ion concentrations obtained from successive $\mathrm{pH}$ measurements (Fig. 5). The figures varied from $8-11 \mathrm{mg} \cdot \mathrm{m}^{-2}$ to over $70 \mathrm{mg} \cdot \mathrm{m}^{-2}$, which corresponds to $0.1-0.7 \mathrm{~kg} \cdot \mathrm{ha}^{-1}$. When analysing the pattern of change in the deposition of hydrogen ions, a certain periodicity and simultaneous downward tendency can be observed. 


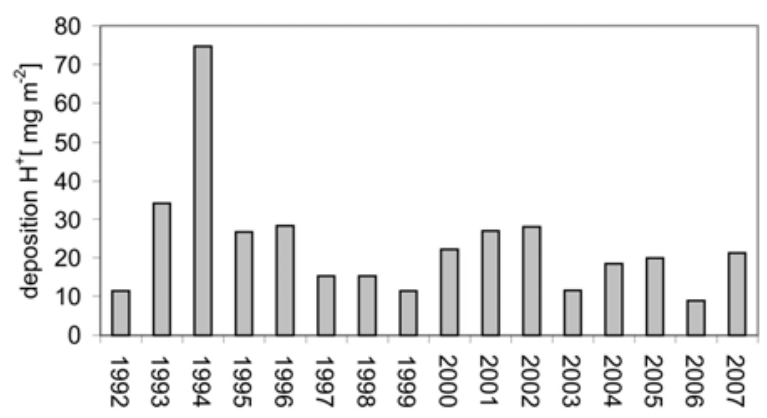

Fig. 5. Deposition $\left(\mathrm{mg} \cdot \mathrm{m}^{-2} \cdot \mathrm{yr}^{-1}\right)$ of hydrogen ions with precipitation, 1992-2007

The presented significant acidity of precipitation is due to sulphur oxides and chlorides of industrial origin as well as transport-related nitrogen oxides in the air. A small role is also played by fluorides, typical of the area under study due to phosphate fertiliser factory located close to the Park and to other regional and supra-regional emitters of this type of pollution. The diagramme (Fig. 6) presents the bulk deposition of these compounds in the years 2002-2007. The deposition of sulphates, unlike the other pollutants, decreased considerably from 2,122 to 1,418 $\mathrm{mg} \cdot \mathrm{m}^{-2}$, while that of nitrates increased to $1,153 \mathrm{mg} \cdot \mathrm{m}^{-2}$. Therefore, the structure of deposited compounds was found to change. It is illustrated by the sulphates to nitrate ratio of deposition, which changed from 3 to 1.5. This is a result of recently lower emission of $\mathrm{SO}_{2}$ in the Wielkopolska region and increasing $\mathrm{NO}_{\mathrm{x}}$ emission caused by car traffic in the Park, on the road from Poznan to Wrockaw running along its border, and on the nearby A2 highway. The above-presented changes are reflected in decreasing average concentration of sulphates, from $3.6 \mathrm{mg} \cdot \mathrm{dm}^{-3}$ in 2002 to $2.2 \mathrm{mg} \cdot \mathrm{dm}^{-3}$ in 2007 , and in increasing average concentration of nitrates, from 1.4 to $1.8 \mathrm{mg} \cdot \mathrm{dm}^{-3}$, respectively. The level of chlorides seems to be quite stable at $0.6 \mathrm{mg} \cdot \mathrm{dm}^{-3}$. However, attention should be paid to extreme concentrations of acid-forming compounds noted during the year. For example, in 2003 maximum

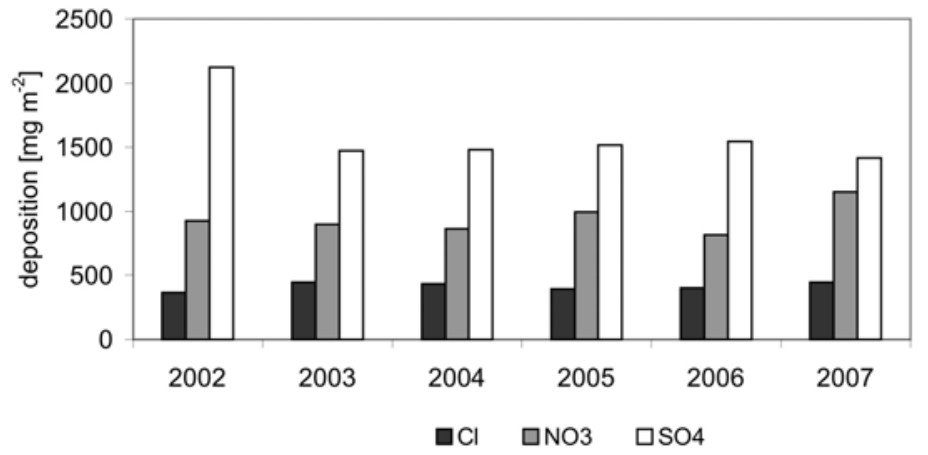

Fig. 6. Deposition $\left(\mathrm{mg} \cdot \mathrm{m}^{-2} \cdot \mathrm{yr}^{-1}\right)$ of acid-forming ions (chlorides, nitrates and sulphates), 2002-2007 
concentrations in a single precipitation event were $45.1 \mathrm{mg} \cdot \mathrm{dm}^{-3}$ for sulphates, 37.2 $\mathrm{mg} \cdot \mathrm{dm}^{-3}$ for nitrates, and $2.5 \mathrm{mg} \cdot \mathrm{dm}^{-3}$ for chlorides. These figures exceed even a dozen times the mean concentration observed in this area. High levels of sulphates were also recorded in the next years: $40.1 \mathrm{mg} \cdot \mathrm{dm}^{-3}$ in $2004,20.5 \mathrm{mg} \cdot \mathrm{dm}^{-3}$ in $2005,19.8 \mathrm{mg} \cdot \mathrm{dm}^{-3}$ in 2006 and $13.6 \mathrm{mg} \cdot \mathrm{dm}^{-3}$ in 2007 . Still, a strong downward tendency in such extremely high concentrations is readily visible.

An annual bulk deposition of fluoride ions is presented in Fig. 7. They are especially dangerous on account of their specific character. The deposition related to rainfall collected in the open area has stabilised over the last few years. However, owing to the high reactivity of these ions, it is crucial to analyse their concentration in each rainfall event.

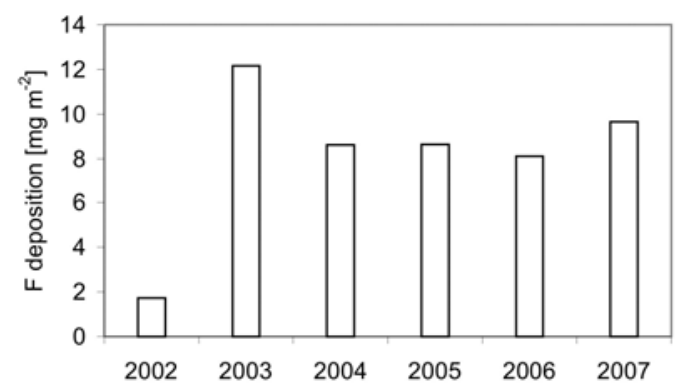

Fig. 7. Deposition $\left(\mathrm{mg} \cdot \mathrm{m}^{-2} \cdot \mathrm{yr}^{-1}\right.$ ) of fluoride ions (bulk), 2002-2007

To illustrate mutual relationships between the concentrations of fluorides in open-terrain precipitation and in throughfall, the pattern of their variability in 2007 is presented in Fig. 8. The diagramme shows that the fluoride levels under trees were from several to more than ten times higher. This indicates significant fallout of fluorides in the form of dust. The annual deposition of fluorides under trees in 2007 was $18 \mathrm{mg} \cdot \mathrm{m}^{-2}$, twice that in the open area. The diagramme reveals also periodicity in the occurrence of fluoride pollution - a decreased concentration in the summer season. This regularity also holds for the throughfall.

The totals of acid-forming substances falling on the Wielkopolski National Park in the recent years were: $70 \mathrm{meq} \cdot \mathrm{m}^{-2}$ in $2002,58 \mathrm{meq} \cdot \mathrm{m}^{-2}$ in 2003 , the same in 2004, 2005 and 2006, and $61 \mathrm{meq} \cdot \mathrm{m}^{-2}$ in 2007. The predominant ions were sulphates, which accounted for $63 \%$ in 2002 , while nitrate ions contributed in $22 \%$ and chloride ions - in $15 \%$. In the subsequent years the percentages of sulphates decreased while those of nitrates increased to $25 \%$ and chlorides to $20 \%$. The deposition of cations $(\mathrm{Ca}, \mathrm{Mg}, \mathrm{Na}, \mathrm{K})$ showed stabilisation over the recent years and remained at $40 \mathrm{meq} \cdot \mathrm{m}^{-2}$. The predominant ion was calcium $(56 \%)$, while magnesium contributed in $12 \%$, potassium in $16 \%$, and sodium in $16 \%$ to the total deposition. The amounts of $\mathrm{N}-\mathrm{NH}_{4}{ }^{+}$in the precipitation amounted on average to 


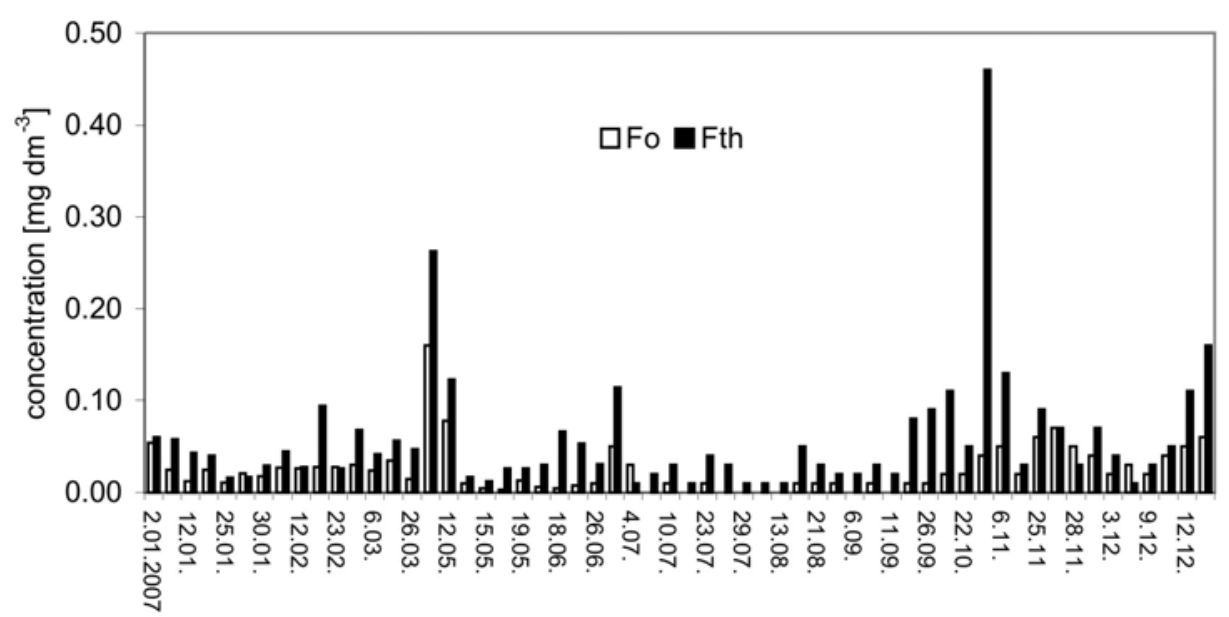

Fig. 8. Concentration of fluoride ions in open-terrain precipitation (Fo) and in throughfall (Fth), 2007

$399 \mathrm{mg} \cdot \mathrm{m}^{-2} \cdot \mathrm{year}^{-1}$ in the years $2002-2006$. It was similar to the country mean (427 $\mathrm{mg} \cdot \mathrm{m}^{-2} \cdot \mathrm{year}^{-1}$ ) but higher than at the station abroad (WALNA and KURZYCA, 2007).

\section{COMPARISONS}

Observations and results of research on precipitation are often compared to obtain information about the level of environmental pollution or tendencies of change. However, results should be compared with caution (KURZYCA et al., 2008). The reasons are as follows. Most significant differences between the results were observed when precipitation samples were obtained in different collecting procedures, both in terms of the mode and frequency of sampling. The differences in the concentrations of particular ions between the corresponding wet-only and bulk precipitation samples could reach $100 \%$. On the other hand, equalisation of samples and results led to differences in the results reaching $20 \%$. Significant differences were also observed among samples undergoing different procedures imposed by the method and time of storage prior to physico-chemical analysis. The type of sample vessel did not affect obtained result, but the type of sampler was important (even the collecting surface was observed to have an influence). The concentrations of analytes in a sample were also found to be changing during the storage time, with $\mathrm{pH}$ changing by even 1.6 units, which corresponded to more than a 15 -fold difference in the concentration of $\mathrm{H}^{+}$.

To avoid the above-mentioned mistakes, annual observations were made based on identical method of precipitation collection and analysis. The research was carried out in the Wielkopolski National Park and in the centre of Poznań city, $25 \mathrm{~km}$ north-west of the Park. Obtained results were compared and their annual 
patterns turned out to be highly similar. The similarity concerned all the analysed ions. Concentrations were usually lower in the Park while extreme figures were recorded on the same day, sometimes with a one-day shift (Figs 9, 10). Such observations show that the main impact on the composition of precipitation in the Wielkopolski National Park was not only the large industrial emitters in Luboń, but also some sources in the city and farther away from the Poznań metropolitan area (WALNA et al., 2004).

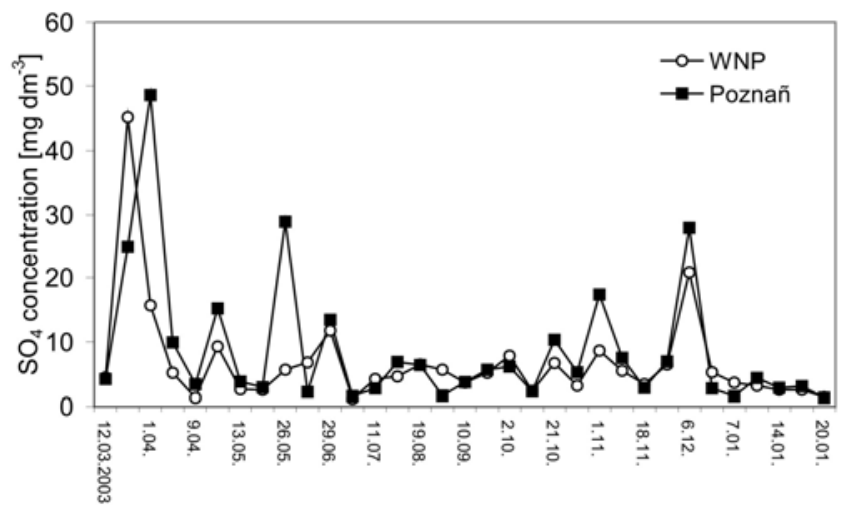

Fig. 9. Comparison of sulphate concentrations in precipitation collected at the Ecological Station (Wielkopolski National Park) and in the Poznań city centre (2003)

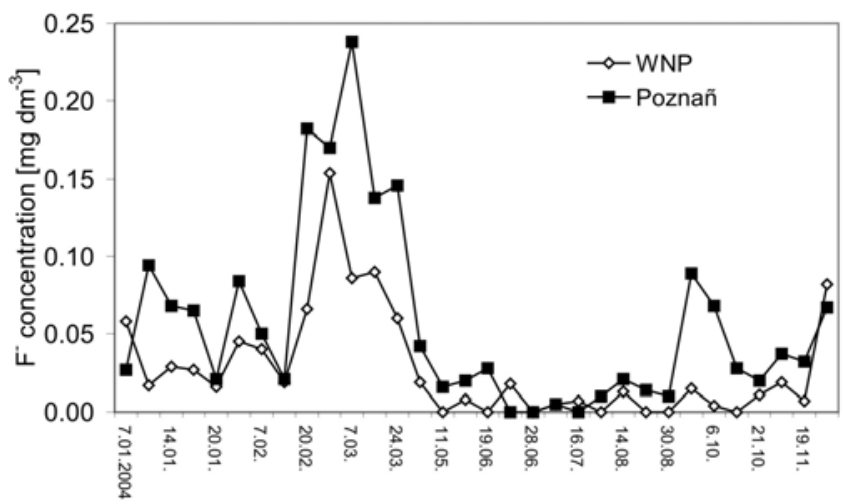

Fig. 10. Comparison of fluoride concentrations in precipitation collected at the Ecological Station (Wielkopolski National Park) and in the Poznań city centre (2004)

A comparison of the quantities of acid-forming substances deposited together with precipitation at different monitoring stations, including those from the EMEP programme, may be burdened with the errors mentioned earlier. However, such a comparison offers an insight into how the proximity of the sea (PL0004 - Łeba) 
can change the composition of the deposited substances resulting from the elevated levels of chloride ions, or how the location in the mountains (PL0003 - Śnieżka, SK0002 - Chopok) boosts the deposition of all the components because rainfall there is twice as intensive as in the lowlands (Fig. 11). Detailed information on the location of the stations can be found in other publications and EMEP materials (MSC-W Report 2005; WALNA and KURZYCA, 2007). The results obtained in the Wielkopolski National Park exceed the figures in the corresponding lowland stations probably because of closer proximity to pollution sources. Also interesting is a comparison of the mean annual $\mathrm{pH}$ values at the selected stations shown in Fig. 12. Here, too, the impact of employed methodology on obtained results should be considered. The $\mathrm{pH}$ figure for the Station in the Wielkopolski National Park is the lowest.

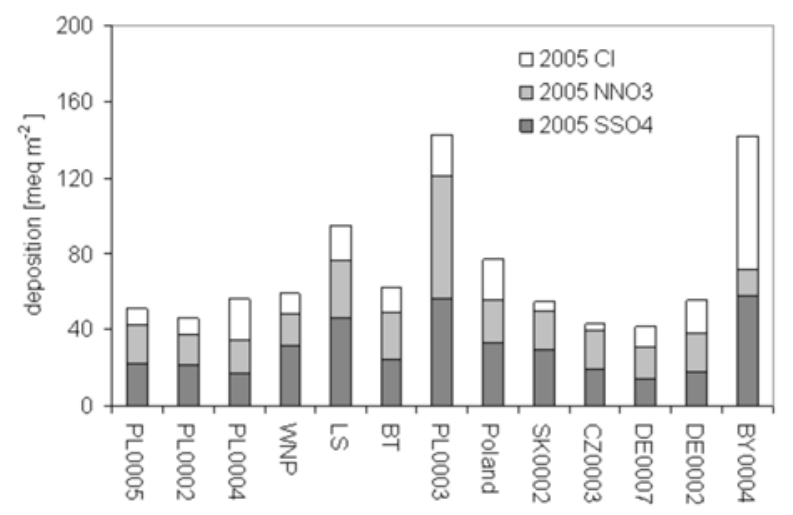

Fig. 11. Comparison of the deposition of acid-forming ions at Polish stations and neighbouring foreign stations in 2003: PL0005 - Jarczew, PL0002 - Diabla Góra, PL0004 - Łeba, WNP - Jeziory Ecological Station, LS - Lower Silesia, BT - 'Black Triangle', PL0003 - Śnieżka, SK - Chopok, CZ0003 - Košetice, DE0007 - Neuglobsow, DE0002 - Langenbrugge, BY0004 - Vysokoe; locations in the map - see WALNA and KURZYCA (2007)

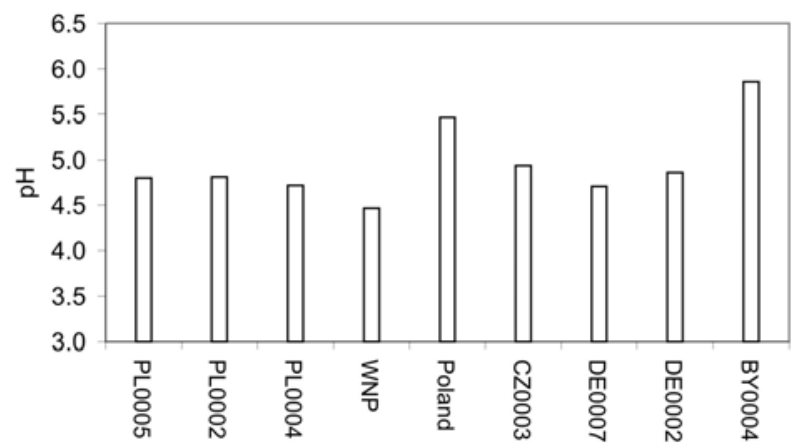

Fig. 12. Comparison of rainfall $\mathrm{pH}$ at various monitoring stations (2003) (descriptions as in Fig. 11) Locations in the map - see WALNA and KURZYCA (2007) 


\section{SUMMARY}

1. The quantitative observations of precipitation show major differences in the annual rainfall. In two years the rainfall was below $400 \mathrm{~mm}$. However, mean annual precipitation in the study period (1992-2007) was similar to the multi-year average.

2. The most unfavourable period was 2003-2005 when the rainfall in the vegetation season was less than $300 \mathrm{~mm}$.

3. The analysis of monthly rainfall sums indicates periods of several months with low precipitation and months when the precipitation was considerably higher than the average.

4. Episodes of quite intensive rainfalls were observed.

5. Precipitation both in the open area and under the trees had low mean annual $\mathrm{pH}$, and the $\mathrm{pH}$ of individual events was often lower than 4.0. However, in the period under study, $\mathrm{pH}$ of open-terrain precipitation and throughfall tended to increase slightly.

6. Precipitation pollution expressed as the means of electric conductivity showed declining tendency. Still, there were rainfall episodes of extremely high pollution. An exceptional accumulation of dust pollution was observed in the throughfall.

7. Several years long study revealed higher deposition of acid-forming compounds in the Park than in the lowland monitoring stations. Their structure in the Wielkopolski National Park changes - the deposition of sulphates decreases and the deposition of nitrates increases. The reason is a lower emission of $\mathrm{SO}_{2}$ in the Wielkopolska region and an increasing emission of $\mathrm{NO}_{\mathrm{x}}$ caused by car traffic.

8 . The presence of fluorides in precipitation, especially in throughfall, should be noted.

9. The Wielkopolski National Park is under unfavourable influence of air pollution intensified by periodic deficits of precipitation causing hard conditions for the forest vegetation.

\section{REFERENCES}

1. Ashenden T.W., 2002. Impact of acid deposition. In: Air pollution and plant life. Eds. J.N.B. Bell, M. Treshow. London, J. Willey and Sons: 263-273.

2. Astel A., Walna B., KurZyCa I., SiePaK J., 2007. Chemometrics in assessment of local and transboundary pollution. Intern. J. Env. Health, 1, 1: 1-12.

3. CZERniak A., KAYZER D., GóRna M., WALna B., 2008. Influence of the Jeziorsko storage reservoir and precipitations on the common oaks growing in the vicinity of Warta River. Pol. J. Env. St., 17, 3A: $135-138$.

4. EMEP/MSC-W, Co-operative Programme for Monitoring and Evaluation of the Long-Range Transmission of Air Pollutants in Europe Status Report, 2005. Oslo, Norwegian Meteorol. Instit. 
5. GóRSKi J., PRZYBYŁeK J., 2003. The problems of anthropogenic threat and protection of ground water at the Wielkopolski National Park area and surroundings, Morena. Pr. Wielkopol. Parku Narod., 10: 59-72.

6. JANSEN W., BROCK A.A., KNACK J., 1988. Acid rain - history, formation, effects. Aura, 4: 18-19.

7. Kowalski Z., 2004. Protection of the Wielkopolski National Park, Morena. Pr. Wielkopol. Parku Narod., 11: 7-15.

8. KRYSIAK D., 2005. Air pollution. In: Report on the condition of the environment in the Wielkopolska region in 2004. Eds. M. Pułyk, E. Tybiszewska. Poznań, WIOŚ: 131-136.

9. KuRZYCA I., Walna B., SiEPAK J., 2008. Reliability of the analytical results - a crucial aspect of research on atmospheric precipitation. J. Env. Analyt. Chemistry, in press.

10. MichaŁowSKi J., RASZKA B., KASPRZAK K., 2003. Spatial management of the Wielkopolski National Park, Morena. Pr. Wielkopol. Parku Narod., 10: 29-45.

11. Polkowska Ż., Astel A., Walna B., Matek S., Mędrzycka K., Górecki T., SiePak J., NamieśNIK J., 2005. Chemometric analysis of rainwater and throughfall at several sites in Poland. Atmosph. Env., 39: 837-855.

12. Statistical data, 2005. Protection of nature. Warszawa, Central Statistical Office: 231-233.

13. UfNAlSKi K., SiWECKI R., 2002. Dynamic of radial increment of common and sessile oaks at test sites in the Woliński and Wielkopolski National Parks. Morena. Pr. Wielkopol. Parku Narod., 9: 7180.

14. WaLna B., KurzyCA I., 2007. Evaluation of bulk deposition in protected woodland area in western Poland. Env. Monitoring Assessm., 131, 1-3: 13-26.

15. WALNA B., KURZYCA I., SiePAK J., 2004. Local effects of pollution on chemical composition of precipitation in areas differing in human impact. Pol. J. Env. St., 13, Suppl.: 36-42.

16. WALNA B., KURZYCA I., SIEPAK J., 2007. Variations in the fluoride level in precipitation in a human impact region. Water Air Soil Pollut. Focus, 7, 1-3: 33-404.

17. WALNA B., SiEPAK J., 1999. Research on the variability of physical-chemical parameters characterizing acidic atmospheric precipitation at the Jeziory Ecological Station in the Wielkopolski National Park (Poland). Sci. Total Env., 239: 173-187.

18. Woś A., 1994. Climate of the Wielkopolska Lowland. Warszawa, PWN: 92-97.

\section{STRESZCZENIE}

\section{Kierunki zmian składu chemicznego opadów atmosferycznych w Wielkopolskim Parku Narodowym}

\section{Słowa kluczowe: depozycja, opad podkoronowy, pH, zakwaszenie}

Przedstawiono wyniki badań chemicznych opadów atmosferycznych, opartych na wieloletnich obserwacjach (1992-2007), prowadzonych w Wielkopolskim Parku Narodowym (WPN) i porównano z rezultatami badań monitoringowych stacji, będących w europejskiej sieci EMEP. Stwierdzono, że w tym czasie pH opadów ulegało systematycznemu podwyższeniu powodując obniżenie rocznej depozycji jonów $\left[\mathrm{H}^{+}\right]$. Linie trendu zmian depozycji jonów wodorowych charakteryzują się zbliżonym współczynnikiem nachylenia, co wskazuje na podobne tempo zmian. Rokiem o najniższym pH był 1994 r., w którym średnie roczne $\mathrm{pH}$ osiągnęło wartość 3,92. Natomiast rokiem o najmniejszym zakwaszeniu okazał się 2006 r. - pH 
4,80. Depozycja jonów wodorowych we wszystkich stacjach monitoringu EMEP w Polsce często przekraczała wartość $20 \mathrm{mg} \cdot \mathrm{m}^{-2} \cdot \mathrm{rok}^{-1}$, a w WPN osiagnęła w 1994 r. wartość $70 \mathrm{mg} \cdot \mathrm{m}^{-2}$.

Przeanalizowano depozycję jonów kwasotwórczych. Wśród nich dominowała depozycja jonów siarczanowych, wykazując wartości malejące w kolejnych latach. Wartości maksymalne wyniosły - $707 \mathrm{mg} \mathrm{S} \cdot \mathrm{m}^{-2}$ (2002) i $260 \mathrm{mg} \mathrm{N}-\mathrm{NO}_{3} \cdot \mathrm{m}^{-2}$ (2007). Stwierdzono wzrastający współczynnik $\mathrm{NO}_{3} / \mathrm{SO}_{4}$ eq/eq, wskazujący na zmiany w strukturze składu anionów. Wśród deponowanych kationów alkalicznych najwyższe wartości przyjmuje wapń stanowiąc ponad 50\%. Stacje nizinne EMEP charakteryzują się wartościami depozycji potasu i wapnia kilkukrotnie niższymi niż uzyskane w WPN oraz niższymi niż średnie dla Polski. W ostatnich latach obserwuje się stabilizację ilości deponowanych kationów.

Reviewers:

Prof. Nicolas Clarke

Assist. prof. Elżbieta Malzahn 